\title{
Israel Geopolitical Impacts on Its Economy
}

\section{Ebrahim Taheri*}

Department of Law and Political Science, Yazd University, Iran

*Corresponding author: Ebrahim Taheri, Department of Law and Political Science, Yazd University, Iran, Tel: +03538210310; E-mail: etaheri@yazd.ac.ir

Received Date: May 22, 2018; Accepted Date: Nov 05, 2018; Published Date: Nov 12, 2018

Copyright: (c) 2018 Taheri E. This is an open-access article distributed under the terms of the Creative Commons Attribution License, which permits unrestricted use, distribution, and reproduction in any medium, provided the original author and source are credited.

\begin{abstract}
As a knowledge-based economy, Israel is on the third step of economic development. This regime has been able to change from an agricultural economy to an essential economy in recent decade of which the most exports are high-tech. Why has Israel intended to become a knowledge-based economy?

In fact, special geopolitical conditions have made the regime try to internationalize its economy through which to get out of the regional isolation. Such a strategy result is that at present time, it is considered as one of the 27 great world economies with 291 Billion USD gross national product, and mostly its exports are to Atlantic pivot countries namely the European, American and recently Southeast Asian countries. This study is to examine the effects of Israel's specific geopolitical conditions on its economy; the method is deductive-inductive.
\end{abstract}

Keywords: Israel; Geopolitics; Development; Knowledge-based economy; Sanction

\section{Introduction}

As early as its establishment, Israel has encountered regional and international legitimacy problems; that is why it has had wars with some Arab countries such as Egypt, Syria, and Jordan. Having signed Camp David Peace Treaty with Egypt and Jordan, almost a type of cold peace was introduced between Israel and Arab countries, but before the peace treaty with Jordan, Islamic Revolution of Iran had led to creating a more intent enemy against Israel than Arabs. By proxy wars against Israel and avoiding direct battles, Iran has succeeded to finish the occupation of Southern Lebanon. Due to wars against Arabs or Iran proxy ones, Israel suffers from sustained loss. Notwithstanding the sanctions have had negative effects on the relations between Israel and its neighbors, the Zionist regime has little regional commerce compared to other parts of the world due to Arab Union sanctions; for example, it has very little commerce with its Arab neighbors; Israel Producers Union announced that in 2014 Israel's exports have been totally 192 Million dollars to Egypt and Jordan. Due to sanctions, many changes occurred in tourist entrance from Europe to Israel in recent years. More than 40 percent of the Israel tourists were from Europe, and after 2000 the rate decreased considerably. The British, Northern European and Dutch tourists decreased 14, 37 and 42 percent, respectively, but the Russian ones increased from 3 to 16 percent in 2013. So, it is possible to propose the question, "Generally what have been the consequences of Israel political geography and geopolitical isolation on its economy?" In response, one may say the most important results have been the economy internationalization by creating a knowledge-based economy, membership in regional, European and universal organizations such as World Trade Organization and the attempt to approach economically Occidental powers in the first 50 years after the regime establishment and creating a balance between new and old powers. The first section of the study examines the conceptual framework in order to realize the hypothesis; the second one generally examines the political geography of the
Zionist regime and especially its geopolitics; the third one examines the effects and results of such conditions on Israel economy and finally, we present the conclusion.

\section{Conceptual Framework}

Geopolitics examines the differences and similarities between the regions with political personality. So political geography examines the effects of actual geographical factors making a country specific and a region strong in universal politics [1].

It is necessary to take into consideration some factors to examine political geography in a region:

A: The nature and existence of an entity. In fact, the question to be answered by all governments to survive is, "Why does a political unit exist independently separated from other ones?" [1]. National unity based on language, religion, and common values or common experiences may be of the most important reasons for a country existence. If the raison d'etre of a country or region disappears and they may not produce another reason for their existence, they will encounter problems sooner or later [2].

B: The Geopolitics of a land and its physical features include some topics such as varied marine compared to limited, and central compared to marginal land and finally strategic situation, the extent, form, the unevenness of the land, climate, mines, marine and land borders.

C: Population and its special features: Scientists consider a land with special political geography features according to some factors such as population, concentration in some parts of the world, a variety of tribes and religions and young population.

D: Geopolitical conditions: During the cold war, geopolitics was used to describe the universal quarrels and wars between the U.S.S.R and the USA to control countries and universal strategic sources. In the 1970s Henry Kissinger, then minister of foreign affairs of the USA, revived the concept of geopolitics and used it as the play between the superpowers in the field of universal balance of power. In the modern 
era, geopolitics is taken into consideration again as foreign politics creator, an analyst of strategic problems and manager of transnational and international affairs. One of the reasons for geopolitics revival is that it comprehensively discusses universal political map. Having presented a great image, it defines the relationships between local, regional changes and universal system as a whole and frames a vast spectrum of events, quarrels and changes as a great unified strategic view. Moreover, based on another modern view, it defines the universal geopolitical system under geo-economic and situational influence to reproduce the globalization of economic, commercial and investing activities, goods and materials transfer, etc. of the governments and their authority and geographical structure of the Earth, too.

Theoretically, geopolitics emphasizes a part of geography joined to power and politics. In fact, power forms the essence of geopolitics and its central core is always the discussion of power and power competition to create superiority over the competitors. Geopolitical science deals with power affairs either after power creation processes or in spatial distribution processes and power replacement or in relation to the universal power structure. On this basis, we may consider geopolitics as a science studying spatial-geographical dimensions of power relationships and national and international politicians' behaviors [3].

\section{Israel's Geopolitical Features}

A: Physical and Geographical Features: Israel has a common border in the North with Lebanon, in the Northeast with Syria, in the East with Jordan and West coast Jordan river, in the Southwest with Egypt and in the West with Gaza Strip. Besides, it is connected to marine ways by the Mediterranean Sea, Aqaba Gulf, and the Red Sea. It enjoys a geographical variety and is not very big. Half of its land is the Negev desert forming Southern Israel. In view of area extension, Israel is the $151 \mathrm{st}$ in the world and is 20,770 sq.km without taking into consideration the occupied regions; about 20,330 sq.km is land. With Golan Heights and Eastern Jerusalem, it is 22,145 sq.km. Total regions under control of Israel are $28,023 \mathrm{sq}$. km of which $27,549 \mathrm{sq} . \mathrm{km}$ is land.

Geographically, Israel zone is narrow and is on the Eastern coast of Mediterranean Sea; in three other directions, it borders Lebanon (in the North), Syria (Northeast), Jordan (East) and Saudi Arabia and Egypt (in the South). The distance between the farthest town in the North (Metula) and the farthest town in the South (Eilat) is six hours $(424 \mathrm{~km})$; its width is 90 minutes $(114 \mathrm{~km})$, the total area covers 20,700 sq.km (7,999 sq. mile).

In the above mentioned geographical territory, the West coast of Jordan River is governed by the independent Palestine regime, and on the west Gaza strip it is controlled by Hamas and Israel has no control over it. In addition, Israel and Syria have disputes concerning the Northeast of the occupied Golan region where the quarrels have been banned by a buffer line created by the UN forces.

One of the actual special geographical problems of the land is its almost arid climate which is not a new issue; the rainfall is low except a little region in the North with considerable rainfall; other parts are arid and it rarely rains. The South region with the considerable area is arid and without water which is very important to be provided with water. The most important catchment basin in Israel belongs to Lake Tiberias fed by Hasbani, Litani and Dan rivers from Hermon mountains and Banias river in Syria. There are five powers (Israel, Jordan, West coast of Jordan River, Lebanon, and Syria) in the catchment basin of Jordan River continued from Hermon mountains to the Dead Sea. The water of Jordan River originates from three tributaries: Hasbani in Lebanon, Dan in Hermon mountains on the Syria and Lebanon border and Banias in Syria. Entered Northern Israel, it joins Lake Tiberias on the Syrian border; after Lake Tiberias in $20 \mathrm{~km}$ distance, another tributary known as Yarmouk formed of Jordan and Syria rivers is added to the basin and finally enters the Dead Sea in $110 \mathrm{~km}$ distance through Bania's Valley [4].

The dispute over water distribution in Jordan River catchment basin has been one of the oldest and most sensible concerns related to water sources among the countries in the Middle East and has been intensified by Israel establishment. The differences became harder because Israeli water network was founded in 1952; the network transfers the water of Lake Tiberias which is one of the sources providing water of Jordan River basin to the Mediterranean coasts, the center of Israel and Negev desert. Such disputes have often led to more quarrels in the region [5].

Considering lack of water and unilateral measures by Arabs, they cut the water of Banias and Hasbani rivers and tributaries of Yarmouk River; such measures were in line with increasing Jordan River water and decreasing water sources to almost 70 percent.

\section{Reason for Israel's existence}

Israel was founded on the basis of religious instructions to establish a land for the Jewish world, but it seems that Israel has not been able to make all Jewish believe, nor has it succeeded to gather many Jewish individuals. The philosophy of its existence disappears without population; by such descriptions, although Israel has defined some existential nature for itself under the title of the Jewish state, nature is refused by the Muslims, and internationally many countries especially the non-aligned ones do not accept Israel's existence.

\section{Geopolitical Challenge}

The Geopolitical challenge and economic problems of Israel to be analyzed exist yet. Although the geopolitical enigma was created by controlling Gaza Strip, Golan Heights and the Sinai Desert, the problem has been since Israel's establishment in 1948. The regional isolation has led to lack of regional economy unification. Dissatisfaction of Arabs concerning Israel became more intensified by Arabic-Islamic revolutions and probably would be completed when Jordan and Egypt governments fall. Permanent quarrel with Palestine and cold war against Iran and its branches including Hezbollah in Lebanon have led to a securitized space in the Zionist regime. If the USA does not back it, it is difficult to imagine how would its future be especially because the regional states do not agree with the United Nations Security Council's decisions and use the military, diplomatic and economic strategies against it. Although in recent years some of them have had commercial and economic exchanges with this regime, the general atmosphere is against this counterfeit regime yet. Peace agreements with Egypt and Jordan have not led to the normalization of relations with other regional states. Although at present time Israel has commercial ties with many countries in the Middle East, such fragile relationships have led to increased transaction costs. In addition, Israeli companies are deprived of the privileges which other Middle East countries have among themselves; so the regime has not been able to benefit from the geographic conditions to improve its economic relations. Disability in benefiting from physical conditions to have relations with others made this state try to use marine and aerial ways to have relations with other countries. Consequently, the 
transportation cost increases and more fuel is used, too; that is why the Israel foreign commerce by land is low namely less than one percent to seriously damage other sectors; for example, although direct and indirect contributions of tourism provide 7.80 percent of Israel gross national product and 8.20 percent of employment [6], tourism has been influenced by the geopolitical isolation due to Israel and neighbors relations in a manner that the Israel tourists were 2.8 million, but they were 4.5 million in Jordan namely the former was half of the latter in 2010. Syria and Egypt had 8.5 and 14 million in the same year, respectively. Finally, it should be noted that only eleven percent of Israel tourists went there by land; the geopolitical isolation has prevented Israel from becoming a transit state and benefitting from regional tourism development [7].

\section{Limited Energy Sources}

One of the most paramount problems of the Zionist regime is its 100 percent dependence on energy import. Although it is the most developed country benefiting from solar energy and is developing the related technologies, it has been a dependent country importing crude oil, coal, and natural gas to provide its necessary energy in recent six decades since its establishment. Historically, all of its energy had been imported from Venezuela and Iran until Islamic Revolution of Iran in 1979, but after the Revolution and stoppage of the energy export by Iran, the energy need has been met by Egyptian sources in the Sinai Desert. The dependence on energy sources has made the Zionist regime vulnerable and especially become prominent in 1973 war and following sanctions by Arabs after the Yom Kippur war. Although at present time, having discovered the first gas field in the Mediterranean coasts in 2009, Israel hopes not to be dependent on imported energy [8]. By virtue of some estimations, the field has both oil and gas; the first phase of the gas exploitation was executed there under the title of Livant in 2012. Presently, it produces 45 percent of the Israel electricity. The Israelis are to be self-sufficient in energy production in the following six years and be an important exporter of natural gas in the world, too. However, there are some important obstacles to Israel to export energy to other countries; the most important one is geopolitical [9]. In common oil and gas field sources of Levitan are shown. This gas field, 19 trillion, is shared among occupied Palestine, Lebanon, Cyprus Republic and North Cyprus Turkish Republic [10].

\section{Population and Related Problems}

Population plays an important role in the security and continuation of Israel's political life. The invasive politics and wars of Israel have considerably influenced the security of the Jewish immigrants in the occupied Palestine and intensified reverse migration. In addition, to reverse migration, Israel has encountered population challenges due to Jewish population; 1.10 percent increase compared to the Palestinian population increase of more than four percent. By virtue of official estimations of Israel Central Bureau of Statistics in March 2013, the population was eight million, of them 75 percent were Jewish, twenty percent Arab and 4.50 percent were other nationalities [11]. In addition to low Jewish population growth compared to that of Arabs, we may mention the poverty and inequality among the people that have encountered the regime with a serious challenge. After Mexico, the poverty rate in Israel is more than all members of OECD in a manner that now about 40 percent of Israel population aged 15-64 years old do not work; only 60 percent of the Arabs and 20 percent of the women work. In contrast, about half of the Haredim women and one fourth of their men work and the rest are active in religious activities. Additionally, the division of labor has been implemented wonderfully. Most of the population have low income. Arabs and the Haredim have the lowest income, approximately 70 percent less than others. The dynamic sector of High-Tech with more than 40 percent of the state exports has created jobs only for seven percent of the population. Some people active in this sector especially in agriculture, construction and tourism have low income and professional security. Moreover, considering the Arabs and Haredim having no considerable education and professional skill, 50 percent of the former and 60 percent of the latter live in absolute poverty. These two groups form 60 percent of the state poor. In addition, the gap between them and that of the regime that is mostly Jewish is increasing; for example, in spite of the occupation increase since 2000 and poverty decrease among the people, the Arabs' and Haredim's poverty has increased twenty percent. The Arabs and Haredim study in different schools and are not generally permitted to do their military service in Israel's defensive forces. Of course, this process dissatisfies them [12]. Such conditions have made 35 percent of the Israelis believe that this country is not appropriate to live and have a tendency to emigrate to other countries, it is while 39 percent of them have stated that life is hard or very hard there. The social demonstration in January 2011 known as 'Hut to Protest against Cheese was against increased price of the products; the second phase of the protest was after that month against increased dwelling rental rate [13].

In 2006 by virtue of an interview by Israel Bureau of Labour with the cooperation of Israel Central Bureau of Statistics in relation to Israelite satisfaction or dissatisfaction, 53 percent of people were satisfied [14]. Although 56 and 42 percent of the Jews and Arabs were satisfied respectively, about 43 percent of the Jews who were older than 20 years had been born out of Israel while the fathers of 39 percent were immigrants. About 18 percent (of the Jews) who were older than 20 or older were the least of the third generation in Israel. Almost all immigrants of the first generation were unsatisfied of being there, and the second ones were more satisfied. Generally, by virtue of the interviews by international organizations in Israel, the Jews are the most satisfied and the happiest people in Israel, while the Muslims have the lowest rate of satisfaction there, the Christians are in the middle [15].

Due to the soft revolution in 2011 for the first time, Israel paid due attention to some problems such as dwelling, health, education and increased expense of daily life. The dwelling price has increased more than fifty percent since 2004, while the real salaries and wages have increased fifteen percent; for example, it is necessary to save the salaries of more than 150 months to buy an apartment. In addition, since 1996 the government has decreased the budget of education, health, and well-being year to year and increased the military one. It should be noted that the citizenship rights of the Israelite Arabs were officially recognized in 1996 [16].

\section{Regime Economy under Sanctions}

It is possible to view economic sanctions on Israel from different perspectives. On the one hand, such sanctions have little effect on its commercial exchange with the European Union in a manner that it can be said such sanctions have had a more mental and psychological effect than any other general influence on foreign commerce and economy; however, such sanctions have had negative effects on Israel and its neighbors' relationships. The Arab Union has very little commerce with the Zionist regime compared to other countries; for example, the commerce between the Zionist regime and Arab neighbors is very low. 
By virtue of Israel Producers Union in 2014, they had 192 million dollar exports to Egypt and Jordan totally [17]. The only sanction by the European Union intensely influencing the Zionist regime is related to tourism and their entrance into Israel in a manner that the tourism rate from Europe to Israel has changed too much in recent years. More than 40 percent of tourists were from Europe and the rate decreased too much after 2000. The British, North European and Dutch tourists decreased 14, 37 and 42 percent, respectively; however, Russian tourists increased from 3 to 16 percent of total tourists in $2013[18,19]$.

The estimations related to Israel commerce based on the reports from the organizations imposing the sanctions show that contrary to the cultural sanctions, the economic ones had not serious effects on Israel commerce because the states imposing the sanctions had not the tendency to execute the sanctions. However, it is necessary to distinguish the goods produced by Israel and ones produced beyond the green line; for example, in April 2013 the European Union countries issued a notice indicating the products produced in the occupied land including Gaza should have the Israel brand so the buyers might choose to buy or not, though the notice was halted by the USA Meanwhile, the European Union made another decision in July 2013 and requested Israel to officially recognize the regions beyond the green line (West banks and East Jerusalem) as the occupied land, otherwise, the European Union would ban it. Also, it has suffered from indirect and silent international sanctions which do not directly ban commerce with Israel, but it is preferable to discuss another commercial partner excluding the risk of Israel commerce; that is why Israeli companies active in Europe, Asia and Africa prefer to work under a foreign brand so they are neither identified nor banned; however, it is difficult to have official information to know how many are such companies. If such a sanction develops, it is expectable that Israel economy would encounter a serious crisis [6].

On the other hand, it is possible to assess the effects of the sanctions on the Zionist regime namely its membership in the European Union. In 2007, Israel proposed the reviewal of cooperation with the European Union in a manner that it would lead to complete political and economic convergence in the Union. After about one year and a half, the European Union agreed with this request. This was a great success for Israel especially against ones stating that the European Union is becoming an anti-Israel tool; however, in 2009 this request was rejected because Israel attacked Gaza.

\section{Specific Geopolitical Results of the Zionist Regime on its Economy}

\section{A move to a knowledge-based economy}

The Zionist regime encounters increasing challenges due to geopolitical isolation and permanent military quarrel against foreign forces and internal extremism. Since having encountered such challenges surely led to the international political isolation of Israel, it has endeavored to go towards a long time knowledge-based economy and the most important result of it is agricultural development leading to the production of the best citrus fruits in Israel and gaining millions of dollars through irrigation systems based on technology. In addition to the agricultural sector, the investments in both software and hardware of military technology have led Israel to maintain its security in the unstable and uncertain environment of the Middle East in spite of its sworn enemies there. The great investments of the regime in research and military industry development have made Israel a world agent in the field of both software and hardware with huge marginal profits so that Israel gains seven billion dollars yearly through selling arms. As a result, it is one of the first ten superior arm sellers in the world [20]. Also having invested in such sectors, Israel has had Hightech and related industries exports more than forty percent. Israel companies have become internationally present in all parts of the world in a manner that at the present time after the UK and Canada, Israel is the third country in view of having the most active companies in the USA. [21]. One of the most important of them is DDS which has installed 45,000 informative-security systems in more than forty countries since 1986; the clients of such a system include Airbus airlines industries, Lucent, Motorola, Nokia, City Bank and Oxford University. Having introduced strong security systems, the nice system provided some of the security systems of Beijing Olympics in 2008; previously more than fifteen Israel companies had cooperated with 200 million supervision projects through cameras in Athens in 2004 [22].

\section{A military-based economy}

During its wars, the economy of the Zionist regime has encountered many functional disorders but has not been damaged seriously so it has been able to revive; for example, fifteen percent of its manpower especially the Arabs did not work during 1973 war so the regime had a little economic disorder; the services sector was damaged seriously so tourism decreased, but industrial and agricultural sectors were as active as pre-war ear. Israeli authorities estimated 14-million-dollar daily production value loss (about 100-million-dollar loss per week). According to some estimations, the regime lost about five billion dollars and 20 percent of the gross national product during the war; after the war, Israel was obliged to buy the USA arms weighing more than 2-3 million dollars. Except for diamond industrial goods, exporting continued and the conditions were the same in relation to agricultural goods [23].

By virtue of the estimations of the Central Bureau of Statistics, the regime's monthly economic development was 0.2 percent during the Israel-Lebanon war especially Gaza crisis indicating how much the crisis had influenced the regime's economy while war decreased the volume of the state economy yearly, the economic budget deficit was 2.8 percent compared to gross national product. War especially influenced industry and production sectors and decreased tourism; that is why central bank decreased bank interest rate to help economic development. The Israel economic development rate reached less than 2.6 percent which was the least during the five years of the war. The foreign investment decrease was considerable in Israel and reached from 10 percent of gross national product to less than 6.5 percent [24,25].

On the other hand, the role played by the extremist forces in and out of Israel has always been a serious security and economic problem. In addition to foreign parameters, internal groups (especially due to increasing poverty of the Arabs there) may threaten internal economy, mental and economic space. We may give an example to show the effect of foreign elements on the economy of the Zionist regime. By virtue of the estimations, Hamas and other Palestinian groups threw 800 missiles at Israel in 2005 and 1,600 ones in 2007 [26]. Although few people were killed because of these attacks, they had a great mental influence on the Israelites; when Sadrat was targeted, it worried the citizens too much. Based on the estimations in 2007, one-third of the Jewish adults and 72 percent of the youth had stress after Hamas and other Palestinian groups' attacks [27]. In addition, these attacks decreased the economic growth and foreign investment absorption; for example, the Israel gross national production was 2.5 percent after 
second Entefaze, Since the end of 2003 when domestic and foreign operations decreased, the Israel economic growth increased 2.5 percent annually $[28,29]$.

All of these conditions have led the regime to develop military industries by which to try to survive and resolve regional security problems; such conditions have led to arms export increase to more than ten percent of total state export rate surely due to high investment in the military sector. For the time being, the military budget of Israel is more than 15 billion dollars and three-fourths of the total state budget. Half of the manpower employed in the industrial sector work in the military section. Although military costs have daily decreased since the 1960s, at present time a high amount of regime budget is allocated to militarism and the highest costs belong to the military sector [30].

\section{Internationalization of economy}

Recently, Israel economy has been tied to the universal economy and is in the third phase of three economic development phases namely in a knowledge-based economy and is one of the 37 superior economies standing with countries such as Germany, Hong Kong, Italy, Denmark, South Korea, Norway, the Netherlands, etc. Also, it is the 27 th world economy in view of gross national production, 10th world economy in view of the complexity and the base of the invention. Israel is the 48th country in the world in view of the economy market size and the 3rd one in view of the world inventions; of course, it benefits from the best research sources and has acceptable financial environment through governmental public policies. At this time, 0.32 percent of the world gross production belongs to the Zionist regime and the per capita income is 37,000 dollars. Israel is the 66th country in view of transparency in governmental economic policies. It is the 16 th in view of judicial independence, 63th in view of infrastructure, 79th in view of governmental budget balance with 3.2 yearly budget deficit, 37th in view of financial market development and 47th in view of market size; however, Israel research departments suffer from not being updated and it is necessary to promote educational potentials because lack of educational conditions especially in the fields of mathematics, science and primary schools might decrease innovation capacity of the regime. With regard to macroeconomic conditions, it suffers from a high budget deficit and disorganized financial policy. The security problem has always been serious there and might negatively influence the economic status [31].

Israel is the 75th importing and 63rd exporting country (with 0.4 percent of the world exportation) of the World Trade Organization (produced goods), 30th country in view of foreign export services, 37 th in view of produced goods commerce and 33rd in view of services commerce; that is why we may claim that Israel economy is based on free market and has been in complete accord with universal economy. Nowadays, there is enough demand for service and industrial goods in the universal market. Although sometimes due to Israel's special conditions such as external wars or internal instability and riots, exports decrease temporarily, the conditions improved immediately. The state service goods have better conditions than the services presented at the universal level indicating the regime's developed economy. The state job market has a relatively favorable condition. The unemployment rate is low and by virtue of maximum manpower participation in the economy, the employment is going daily towards complete employment. The regime has economic stability, and financial and banking systems have been able to ensure the economy against the internal and external shocks. Price stability is the most important aim of the regime; of course, it is gained through some aims such as decreasing the inflation, maintaining economic growth at a logical level, decreasing unemployment and keeping financial stability. In recent months, the inflation rate has been less than the annual rate and the prices have decreased 0.3. In addition to the above advantages, the Zionist regime's some potentials made it a distinguished concentrated economy in the Middle East. Very expensive high educated manpower, high rate of research and development (3.9 percent of the gross national production) mostly conducted by the private sector and the important role of technological industries are other strong points of its economy [32,33].

The Israel investment system is run liberally and all fields are open to private sector investment and internal investors. After the considerable decrease in 2009-2010 due to the universal economic crisis and especially the USA economic problems (Due to the Zionist regime independence from the USA and universal economy), direct foreign investment decreased. After 2011, the regime's foreign investment improved and it increased 48 percent in 2013 compared to 2012. Factors making the state appropriate for foreign investors include high investment in research and development in different fields, skillful and educated manpower and special conditions for foreigner investors through general regional instabilities in the Middle East. The role of Israel in such instabilities influences more or fewer foreigners' investments [34]. The rate of direct foreign investment in Israel economy in 2005-2014.

It should be noted that foreigners' investments in Israel stock market have been 65, 74 and 88 billion in 2011, 2012 and 2013, respectively [35]. When most important investors were the USA (26.50 percent), Cayman Islands (11.60 percent), Canada (six percent), Netherlands (5.2 percent), Singapore (2.5 percent), Britannia (2.1 percent) and Switzerland (1.7 percent); the investments have been in the fields of real estates, business and commerce (30 percent), mines (7.4 percent), production and factories (6.9 percent), financial sector (4.5) and construction (1.7 percent) [36].

\section{Trans-regional vs. regional unification}

During the first 50 years of the Zionist regime establishment, the regime's central focus was on economic and industrial development towards Occident especially the USA and Europe; Israel tries to target mutual agreements and free commerce and develop economic relationships with other countries. Israel is the most important commercial partner of the European Union in the Mediterranean region and the latter which is the first commercial partner of the regime based on the commerce rate to reach 29 billion dollars of commerce in 2014 [37]. The main important exports from Europe to Israel have been machinery, transportation equipment, chemical materials and other similar products. By contrast, the most important Israel exporting goods to Europe include chemical materials, machinery, transportation equipment, fuel materials and mineral products. Israel has witnessed more than 17 billion dollar imports and 12.50 billion dollar exports to the European Union in 2013 [38].

Israel had 36 billion dollar commercial interactions with the USA in 2013; it was the 23rd goods exporting destination of the USA which had 4 billion dollar exports to Israel and the latter had 23 billion dollar exports to the former. The most important USA exports to Israel included precious stones (for example, diamond: 5.8 billion dollars), electronic equipment (1.6 billion dollars), machinery (one billion dollars), airplane (823 million dollars) and medical supplies (666 million dollars). The USA agricultural products exports to Israel were 
estimated 627 million dollars. Israel is the 21st country providing necessary goods for the USA with 23 billion dollars in 2013 [39]. The most important goods imported from Israel to the USA include precious stones (9 billion dollars cut diamond), pharmaceutical products ( 5.4 billion dollars), electrical machinery (1.4 billion dollars), medical supplies ( 1.3 billion dollars and agricultural products $(327$ billion dollars) (Office of the United States Trade Representative, 2015).

Considering the World Bank data including Israel commercial balance from 2005 to 2012, the highest commercial deficit of Israel was more than 1.5 billion dollars of negative merchandise balance in 2007 . In contrast, it had 500 million dollars of positive merchandise balance in 2012. Based upon the data issued by the European Economic Development Commission, Israel had commercial deficit amounting more than 4 billion dollars, 4.3 billion dollars and 4.5 billion dollars in relation to industrial goods with the European Union in 2011, 2012 and 2013, respectively. Also, it had commercial deficit more than 1.2 billion dollars, 1.4 billion dollars and 1.3 billion dollars in relation to services sector in 2010, 2011 and 2012, respectively. As indicated in the Israel had positive merchandise balance as compared to the USA in 1996-2014, and inversely its merchandise balance was negative as compared to the European Union.

However after 2000, the development of commercial relations with new important economic countries such as China, India, Russia, and Brazil was proposed as a priority for Israel's foreign policy; simultaneously it focused on creating a balance between East and West commercial relations such as changes originated from the risk of economic sanctions by the European Union against Israel, Islamic world influence in Europe, the USA decline and lack of motivation to be present in the Middle East and the change of power balance between East and West in favor of the former in the following decades. Israel had some programs to implement its strategies; for example, it tried to close Israel Commercial Office in Sweden and Finland and opened similar offices in China, India, and Brazil. Similarly, the previous minister of defense of Israel and its ambassador to the USA, Moshe Arens said Israel is gradually going towards East and going away from Europe; however, it should be noted that the relations with Eastern countries are less than with the USA and Europe.

The economic relationship development with Asian countries such as China, India, Japan, Malaysia and Bangladesh is important; that is why at the present time in addition to Europe and the USA, more than one-third of Israel exports are sent to the Asian countries especially China and India; this process was after the worry concerning antiJewish operations in Europe and the fear of sanction by the European Union especially the anti-Jewish groups did something against the Israel companies in Denmark and the Netherlands and worried the managers of the companies. Then, the Israel cabinet set the attempt to decrease the dependence on West, especially on Europe as an agenda for its government. Presently, Asia is the second important commercial partner of Israel in the world and one thousand (of three thousand) Israel companies are active in Asia especially in China, India, Malaysia, and Vietnam. The Israelites are to export half of the produced goods to Asia especially to Southeast Asian countries until the end of 2016.

In line with this process, China and India are especially very important for Israel. Now, Israel has a close relation with India; perhaps it would be interesting to note that when Narendra Modi was the Prime Minister of Gujarat, the Israelites invested there too much and became one of the most important economic development columns there. As a consortium, two Israel companies are known as
Nasdaq and Tsem and IBM had negotiations for investment in India, so more than 10 billion dollars was invested by them in Gujarat and New Delhi with the cooperation of Malaysian and Switzerland companies to produce two semiconductor production factories. Due to these measures, Gujarat became an example for other parts of the world and Modi was elected as the Prime Minister because he was successful in the state economic development. Having been selected as prime minister, the fortification of relations with Israel was set as an agenda and as it would be mentioned later, signing free commerce agreement between these two countries was finalized in 2015 .

However, at the end of 2015 the most important destinations of the Israel exports are as follows: USA (23 percent), Britain (8.6 percent), Germany (7.3 percent), Netherlands (6.5 percent), Italy (4.6 percent), China (5.1 percent) and India (5.1 percent; some sources indicated 9.1 percent).

Israel is a member of the World Trade Organization, International Monetary Fund, and the World Bank. As a little power, it has little influence on these organizations, but it has conveniently shown its influence on different forums and has been able to defend itself and has created positive progress among them.

It has an exceptional condition in regional organizations such as the European Union. In line with this, the first mutual agreement as free commerce contract was signed under the title of Europe-Israel Association Contract in 1995 and was executed in 2000; it was to create permanent political negotiations, a free market and more cultural, economic and social cooperation. The second agreement was signed by the virtue of European neighborhood policy; in this agreement, Israel is the only state mentioned as a privileged neighbor and in line with this, some agreements have been signed at the highest levels of science and technology among these units and Israel. Nowadays, by virtue of agreement the regime has benefited from some privileges such as the elimination of customs tariffs to enter the market of the European Union, entering domestic market of the European Union, vast information exchange and scientific and technologic consultations in the fields of culture, science, industry, education and environment [40]. In addition, it became a member of Economic Development and Cooperation Organization in 2010 which was a climax in the regime's position improvement [41]. Membership in the organization was not merely a symbolic gesture, but it was the result of long-term diplomatic attempts needing legal reforms and adjustments. The organization was to introduce some standards in the world policy and to share information [42].

\section{Conclusion}

The Zionist regime has encountered several difficulties since its establishment in 1948; some of which are as follows: small population size, numerous immigrants, non-acceptance in the region (many enemies, few friends), a small territory, few sources, water crisis and geopolitical isolation. These conditions have intensely influenced different political, economic and military sectors in the country; among which economy has suffered more than military and political sectors. Then, the state economy has become knowledge-based focusing on the army and independent from the West in the first 50 years from 1948. It should be noted that after 1990, the policy makers of Israel tried to set agendas to improve their relations with new powers such as China and India and have some privileges due to their technological capacity. 


\section{References}

1. Dare M (2006) The Fundamentals of Geopolitics. Tehran: SAMT.

2. Mostafa M (2004) An Introduction to Geopolitics and Iran's Strategic Significance. The Journal of the Faculty of Law and Political Sciences. 63: 203-221.

3. Mohammadreza H (2006) Principles and Concepts in Geopolitics. Tehran: PAPLI

4. Eugenia F (2008) The Effect of the Israeli-Palestinian Conflict on the Water Resources of the Jordan River Basin. Glob Environ 1: 152-160.

5. Eugenia F (2010) The Water Issue in the Mediterranean. European Institute of the Mediterranean, pp: 1-14.

6. Efraim I (2013) Israel Is Not Isolated.

7. Sharon A (2013) Alliance In Crisis: Israel's standing in the World And the Question of Isolation.

8. Pozo MA (2009) Spain -Israel Military, Homeland Security and Armament-Based Relation Affairs and Trends.

9. Kaplan J et al (2014) Investing in Israel Impact of Geopolitical Ris.

10. Library of Congress (2014) Regulation of Foreign Aid:Israel.

11. Israel Central Bureau of Statistic.

12. OECD (2010 )Israel: a divided society, Results of a review of labour market and social policy.

13. Shachar G (2012) Israel's Retail Food Sector, Tel Aviv, USDA Foreign Agricultural Research.

14. Jane B, Mary A, Prados B, Jeremy MS (2006) Qualifying Industrial Zones in Jordan and Egypt. CRS Report for Congress pp:1-6.

15. Van Praag BMS, Romanov D, Carbonell FA (2010) Happiness and Financial Satisfaction in Israel: Effects of Religiosity, Ethnicity, and War. Pp:1-32.

16. Gorodess T (2013) The People Demand Social Justice: How the Israel Social Protests Ignored the Palestinian Issue, and the Road Ahead. ICSR Atkin Fellow pp:1-17.

17. The Economist (2014) A campaign that is gathering weight.

18. International tourism, number of arrivals," The World Bank, 2009-2011, “Travel \& Tourism: Economic Impact 2013, Israel," World Travel \& Tourism Council,

19. Sheffielf C (2014) Boycott Israel Movement Stunts The Palestinian Economy.

20. Flug K (2014), " Strengths and challenges facing the Israeli economy. Bank for International Settlment. Pp: 1-2.
21. Zetelny I (2014) The Israeli Hi-Tech Industry.

22. Gordon N (2009) The Political Economy of Israel's Homeland. QSPACE.

23. CIA (1973) Israel: Economic Impact of the War.

24. The JP Updates (2015) CBS Stats: Israel's Economy Actually Grew During Gaza War.

25. Puder J (2015) Security Challenges Facing Israel in 2015.

26. Paul B (2007) Germany's Relations with Israel: Background and Implications for German Middle East Policy. CRS report for congress pp: $1-19$.

27. Dotan P (2007( The Economic Effects of Terrorism: Counterfactual Analysis of the Case of Israel.

28. Konstantinos D, Kutan AM (2003) Regional Effects of Terrorism on Tourism in Three Mediterranean Countries J Conflict Resolut 47: 621-41.

29. Zvi E, Tsiddon D (2004) Macroeconomic Consequences of Terror: Theory and the Case of Israel. J Monet Econ 51: 971-1002.

30. Fischer S (2013) Challenges facing the Israeli economy Remarks by Professor Stanley Fischer, Governor of the Bank of Israel, upon taking leave of the Knesset Finance Committee, Jerusalem.

31. Schwab S (2015) The Global Competitiveness Report 2014-2015. World Economic Forum, Geneva, pp:1-565.

32. The Spiegel (2015) Holocaust Reparations: Germany to Pay 772 Million Euros to Survivors.

33. The Times of Israel (2015) Israel among most corrupt developed states, study finds.

34. Index M (2015) Israel - Foreign direct investment.

35. Santandertrade (2015) Israel: Foreign investment.

36. Central Bureau of Statistics (2015) Finance and Capital.

37. The Unctad (2014) General Profile: Israel.

38. CPI (2014) Corruption Perceptions Index 2014. Transparency Int: The Global Coalition against Corruption.

39. Coren O, Feldman N (2013) US aid to Israel totals $\$ 233.7 \mathrm{~b}$ over six decades. Haarets.

40. Agnes BS (2012) EU-Israel Relations: Promoting and Ensuring Respect for International Law. Euro-Mediterranean Human Rights Network, Brussels.

41. Halevi N (2010) Trade, Aid and Economic Dependence-Evolution of Israel $^{\text {ec }}$ s foreign economic relations.

42. OECD (2013) OECD Economic Surveys: Israel. 